\title{
Patriarchy \& unwed mother of Odisha
}

\author{
Sunita Behera ${ }^{1, *}$, Urmimala Das ${ }^{2}$ \\ ${ }^{1} \mathrm{PhD}$. Scholar, ${ }^{2}$ Reader, Berhampur University, Women's Studies Research Center, Odisha, India
}

*Corresponding Author:

Email: sunita.behera306@gmail.com

\begin{abstract}
This article starts with the presumption that women experience gender in different ways. For example, Black women experience various forms of oppression simultaneously, as a complex interaction of race, gender, and class that is more than the sum of its parts. By focusing on gender as the primary locus of oppression, main-stream feminist legal thought often forces women of colour to fragment their experience in a way that does not reflect the reality of their lives .The recognition of women's differences, however, does not negate the fundamental premise of feminism that women are oppressed "as women ."'It is still, therefore, useful to make patriarchy a focus of feminist inquiry and opposition. How, then, do we understand our condition as women and work towards our liberation? Recent feminist scholarship has established that racism makes women different, even though women are all subject to patriarchy. What I wish to examine is the relationship between racism and patriarchy.

Racism and patriarchy are not two separate institutions that intersect only in the lives of Black women. They are two interrelated, mutually supporting systems of domination and their relationship is essential to understanding the subordination of all women. Racism makes the experience of sexism different for Black women and white women. But it is not enough to note that Black women suffer from both racism and sexism, although this is true. Racism is patriarchal. Patriarchy is racist. We will not destroy one institution without destroying the other. I believe it is the recognition of that connection along with the recognition of difference among women that is truly revolutionary. ${ }^{1}$
\end{abstract}

Keyword: Feminism, Family issues, Social relationship, Education and case studies of unmarried mother.

\section{Introduction}

Adrienne Rich distinguishes between the "experience of mother-hood" -the relationship between a woman and her children -and "motherhood as enforced identity and as political institution."' An unwed Black teenager, for example, may experience motherhood as a rare source of self-affirmation, while society deems her mother-hood to be illegitimate and deviant." She may experience caring for her child as a determined struggle against harsh circumstances, while society sees in her mothering the pathological perpetuation of poverty. Some women may experience mothering as debilitating and intrusive, even though patriarchal ideology defines it as woman's instinctive vocation. Some women may experience fulfilment and happiness in mothering, even though feminist theory calls it oppressive. ${ }^{2}$

Society's construction of mother, its image of what constitutes a good mother and a bad mother, facilitates male control of all women. Women who fail to meet the ideal of motherhood (unwed mothers, unfit mothers, and women who do not become mothers) are stigmatized for violating the dominant norm and considered deviant or criminals. Martha Fine man calls motherhood colonized an event physically practiced and experienced by women, but occupied and defined, given content and value, by the core concepts of patriarchal ideology."

This is patriarchy's meaning of motherhood, one designed to serve the interests of men. The meaning of motherhood in America, however, is melded, on the basis of race as well as gender. Patriarchy does not treat
Black and white motherhood identically. In America, the image of the Black mother has always diverged from, and often contradicted, the image of the white mother. $^{3}$

There are several areas to be examined in the study of racism and patriarchy in the meaning of motherhood. This article is directed to the diverse community of feminist thinkers, as it concerns the construction of motherhood by those in power. The article also raises issues for discussion within the Black community, issues that Black feminist scholars are continuing to address, including: the meaning of motherhood within communities of colour; sexism by Black men; and the need for Black women to confront our own differences and to develop solidarity among ourselves. For example, Audre Lorde writes about Black women's need for one another: "There are two very different struggles involved here. One is the war against racism in white people, and the other is the need for Black women to confront and wade through the racist constructs underlying our deprivation of each other. And these battles are not at all the same. "My focus here on the dominant meaning of motherhood does not minimize the critical importance of Black and other mothers' self-definition.

\section{Family issues \& Unwed Mother}

Family relations: Majority of the unwed mothers $(72 \%)$ were having either poor family relation or average family relations. Only 28.1 percent were having good family relations. This shows that unwed mothers were lacking good family relationships. Chi 
square value computed for testing the association between family relation and circumstances was found to be non-significant at 0.05 levels. This shows that there is no association between family relation and circumstances. Though it was statistically nonsignificant it was noted that percentage of unwed mothers having high family relation were comparatively lesser than that of the unwed mothers having low and average family relations.

Social relations: Majority of the unwed mothers (96\%) were having either poor social relation or average social relations. Only 3.8 percent were having good social relations. Significant chi-square value at $\mathrm{p}=0.002$ indicate that there was significant association between social relations and that of circumstances. Results shows that in the case of respondents having only low and average social relation, the circumstances which led to unwed motherhood was love affair compared to rape. However, among the case of respondents having high social relations, the chance for rape and love affair was equal.

\section{Family life education among unmarried women}

The objective of family life education is providing knowledge about the physiological features of women as they grow up and make them understand the norms of marriage and reproductive health of women. In DLHS-3 right knowledge and source of information about RTIs /STIs, HIV/AIDS, Family Planning, Family Life Education, Marriage and Reproductive Health were collected from unmarried women aged between 15-24 years.

In all 7,257 unmarried women were interviewed in Orissa, of which 69.8 percent were between 15-19 years and the remaining 30.2 percent were between $20-24$ years. In rural areas unmarried women in the later age group is 29.5 percent as against 34.7 percent in urban areas. One-fourth (25.3 percent) of the unmarried women in rural areas have 10 or more years of education and among urban unmarried women, 56.2 percent had more than 10 years of education. Highest proportion of unmarried women age 15-24 years belongs to other backward classes in rural areas and other castes in urban areas (31.1 percent and 44.6 percent respectively). In urban areas more than twofifth (47.4 percent) of unmarried women were from richest households.

Little more than three-fourth (76.5 percent) of women were aware of Family Life Education. Awareness about Family Life Education among women age 15-19 years is below the state average among unmarried women who live in rural areas, have lower levels of education, belonging to schedule caste and schedule tribes and women from households belongs to lowest wealth quintile. There is a significant gap between the level of awareness and perception of importance of Family Life Education among the unmarried women in Orissa by selected background characteristics. Forty two percent of women were of the opinion that Family Life Education should be given by age 12-14 years. As many as 39.5 percent of unmarried women felt it is important to provide Family Life Education before reaching tenth standard.

As regard the opinion on ideal persons who should impart Family Life Education, 86.2 percent of unmarried women felt that parents should provide them Family Life Education, while 60.8 percent women were of the view that it should be provided by brother/sister/sister-in-law. Thirty-eight percent had viewed that it should be provided by teacher/school/college and 22 percent women were of the view that it should be provided by friends/peers. Only 4.3 percent of unmarried women mentioned that healthcare providers /sex education experts were ideal to impart such education.

Little more than two-fifth (43.6 percent) of the unmarried women in Orissa had received Family Life Education. The main source of education is other sources (57.6 percent), followed by school/college (50.5 percent), 3.7 percent from youth club, 3.6 percent from government programme/camp and 2.4 percent had received Family Life Education from a NGO programme /camp.

It has been observed that around 8 out of 10 of unmarried women (between 15-24 years) have the knowledge of minimum legal age of marriage for boys and girls (82 percent for boys and 84 percent for girls) aged. Seventeen percent reported ideal age of marriage for boys as less than 21 years while the remaining 83 percent reported more than 21 years. On the other hand, almost all women (96 percent) in the age group of 1524 years reported the ideal age of marriage for girls is 18 years and above. ${ }^{8}$

\section{Case 1}

\section{Ms. Rebati Behera}

Rebati Behera is a 25 years old lady from Gouranga Patna, Po-Madhurachua, Dist-Ganjam. She belongs to a very poor family having yearly Rs.90, 000/- yearly income. They used to go for daily labour at the time of transplantation and Pedy cutting. She is from a landless family.

She was living with her parents and three brothers and three sisters in Gouranga Patna village. Rebati is educated up to class fifth when she is around 12 years. She has left schooling since then. At that time she was engaged in house hold work and she was also going for wage labour. She got puberty when was around 10 to 11 years old. Within her 14 years of age she was quite free in mixing with neighbour and other people of village. In addition to house hold work she was mostly going out to fetch water for the family, to collect firewood from the nearby jungle. For all there are daily work, she was going out to take bath to the public pond and to defecate outside in open ground and also going out for marketing of the family. While discussing with 
her, we observed that her mobility outside the house made her vulnerable to come in contact with Narayana, who was a neighbour of Rebati, aged about 20 years old by that time Narayana was quite matured by the time and he was cousin brother of Rebati. Rebati was very often visiting the grocery shop of Narayana, for the purpose of marketing which was near to Rebati's house. Very often she was meeting Narayana some purpose or other. Narayan was educated up to intermediate by that time when he was 20 years old. The girl was very beautiful, young active and mobile. Narayan was impressed with this girl when Rebati was minor only 12 to 14 years old. She was hardly aware of social costumes, legal norms, physical and sexual vulnerability. The intermixing between this two young people very frequently made them intimate as they were very close relative. So their intimacy was beyond the imagination of elder persons or uncle, aunty, elder brother sister of both the sides. Father of Rebati and Father of Narayana were two brothers from same mother. In reality Rebati and Narayana were in brother sister relation having blood relation. Their relationship became closer day by day with in two years of their intimacy. She becomes pregnant when she was 14 years old. She came to know about this when she skipped out 3 months of her menstrual period. After that when she confirmed about her pregnancy, both of them discussed about that and decided to elope from their village to for away distance to Bangalore. But in that night parents of Narayana came to know about their planning and made a plan to send their son to an unknown place to avoid Rebati. Narayana went off to Bangalore without the knowledge of Rebati. Parents of Rebati filed a case against Narayana. But police did not take any action against Narayana and his family. Police took Rebati to central home for shelter as she was pregnant. This news spread like wild fire in the nook and corner of the area, village and beyond it. The villagers denied water and fire to that family. The family was out casted from the daily activities of the villagers. After paying the penalty of rupees 10 thousand the villagers allowed the family to mix with other villagers and the discrimination of fire and water was waved. A boy was born in the central home after six months. But Rebati and her son stayed there for 2 years more after her child birth. When she became 18 years old, she was released from the jail along with her son. Now, after seven years, Rebati is working as a labourer and she has left her son in a orphan centre. When the child was small, Rebati was at her place and she managed to survive herself and also the survived her son depending on the wages as she was working as a labourer. At the beginning when she came to home, her parents scolded her very badly, she had to tolerate all those abuses of her parents as she had no way out. With the passage of time, all became used to stay together, earn together and manage the house. She was managed to send money to her son to school and for private tutoring in the village. Within seven years, she tolerated a lot from neighbours, villagers and also from the relatives. Her son had to listen many abuses and sarcastic comments from his schoolmates and village peoples. The boy seems to be talented to one on his study and was also a good looking boy. Keeping all these in her mind, Rebati had tolerate very bad comment on her son and became strong enough to send him to orphanage, when he was seven years old. Keeping the tears back with in her eyes and within her heart, she eschewed all pathos and now staying along with her parents.

As Rebati was a beautiful girl, many persons proposed to marry her but with a condition. The condition has to abandon her child and also her poor parents. But Rebati could not agree to these conditionality and till date has remained unmarried. Rebati is living a life of pain and turmoil .Neither she can marry because of the taboos, tradition, custom and above all for the unlawful child birth she has given without wedlock. While analysing the case studies of Rebati, many question, confusion, ethics and code of conduct, costumes arises which needs further probing and academic debate.

\section{Case 2}

\section{Ms. Kusuma Nayak}

Kusuma and Niranjan Nahak also working in same place in the year 2014. There is a small village named as Aliabad situated about two KM. away from Ganjam. The girl named Kusuma Nayak was living in this village. She was the only daughter of her parents. She lost her mother in her early age. There was no one closer to her except her father in her life. They are used to work as wage labourer to survive and spent their live. Unfortunately, her father got illness for which they were facing so much obstacles as no one left her family to earn except Kusuma. Her father was not able to do any kind of work and was always on the bed like a dead body. Kusuma used to go to Ganjam for their daily work.

Due to lack proper financial condition Kusuma was not able to study higher education. She only managed to read primary level of education. Niranjan managed to study up to seventh class. They were both working in the same place. As they were working in the same place both were meeting each other and returned home after completing of their work. There is a daily conversation and meeting slowly slowly converted into love. It becomes dark when they returned from their work.

There is a pendants shrub on their way to home. By the way, Niranjan seduced and kept physical relations with Kusuma on a promise of marriage. Finally, Kusuma also got agreed on his proposal and they were a keeping physical relation many times without any fear under pandanus shrub. Kusuma never revealed this matter to anyone. Few months later, Kusuma come to know that she was pregnant. When Kusuma on 5 months of pregnancy, father of Kusuma got clue of it somehow as hint and asked to Kusuma about that. 
Kusuma also revealed everything without hiding. Then Kusuma's father discuss this matter with his fellow villagers. They decided to go Niranjan's home. When they reached there, they had got shocked to know that was already a married person and was a to there of daughter. Niranjan did not admit his fault of keeping sexual relation with kusuma and also refused he had never in relationship with Kusuma. He also denied that the child who growing was in Kusuma's womb had no relations with him.

Then Kusum's father filed a complaint case in the police station against Niranjan. Kusum was sent to Berhampur hospital for checkup. As per Report it came to light that she was pregnant. But Niranjan was not in a state that to admit his fault. Then Kusuma's father took this case to High Court. Finally Kusuma got justice and Niranjan got punishment for his offence. Till now Niranjan is in jail. But for Kusuma it was too late for abortion. Kusuma did not wish to give birth this child but doctor says that it was too late. She has to birth this child. Then Kusuma have no any other option. She had to give birth this girl child. Then kusuma had no any other option. She spent her life with her daughter at her parents. Her father is managing Kusuma and her daughter as a daily wage worker. They are living their life with pain and difficulties.

\section{Case 3}

\section{Ms. Buyjayanti Pattanaik}

Buyjayanti Pattnaik had 4 sisters. Biju was youngest among all. They have no brother. Biju was not able to complete her study due to poor financial condition. In her childhood time her mother left them. Biju and three sisters also got married. Biju's father was physically disabled. They four of the sisters worked as daily wage labourer and also taken the responsibility of family. Even they got married with their small personal savings. There after only two members i.e. Biju and her father were left then her elder sister's got married. Once Biju's one of sister got ill and Biju had to go to her sister's home the village Kuhudi of Khorda. Biju's elder sister's name Chinta Pattnaik and her husband's name Niranjan Pattnaik. Biju stayed there about four months. Chinta Pattnaik has two daughters'. As Biju stayed a relation developed between Biju and her sisterin-law. But no one had noticed that. After few months Biju's sister felt well and Biju returned to her home. Her sister-in-law also came along with Biju. Slowly their relation converted into love and then it ended in physical satisfaction. Biju never revealed such relation to anybody. After few months she came to know that she was pregnant and she kept it secret. After four months of has pregnancy she could not keep it secretly for long as she informed to her father. Biju's father, discuss such matter with Niranjan. As a result conflict started between two families. Then Biju used to stay at Niranjan's home. Niranjan's family used to abuse her and mentally tortured Biju. Biju's sister was also involved with them. There was always quarrel in the family. In such situation Niranjan did not react. He knew that he had no way other option except to keep silence. After few days Niranjan died in a road accident. That time Biju was seven month's of her pregnancy. A far Niranjan's death his family had no sympathy or mercy towards Biju and they disposed of her from their house. They abused her in bad language and also criticized that Biju was reason behind Niranjan's death. In such situation Biju's sister remain silent without reacting. Then Biju had no patience to survive in such kind of situation and finally she returned to her father's home. She gave birth to a boy child in her paternal home. Now Biju works as a daily wage labourer and used to go several houses for work and the money she earned from her work is the only source for earning daily food for her child and father. In such a situation Biju survives and struggles to live and spend her widow life with full of tears.

\section{Case 4}

\section{Ms. Sradhanjali Pradhan}

It was an incident of 2007. Sradhanjali Pradhan and Pradeep Tripathy both were in love relation with each other madly. They did not remain apart from each other for a minute. Pradeep belonged to Brahmin caste and he was residing in Kumuri Dharmasharanpur. At that time when Shradhanjali was 17 years old Pradeep was at has 21. Both read up to intermediate in the same college. Both had spent most of their of times with talking to each other over phone and also in other place. After reaching the college they used to the leave college without attending the class for spent times together. Their families came to know about their relationship and also shouted at them. Despite of his families warning, they were meeting regularly without any fear. Once the parents of Sradhanjali keep her in a room and locked outside. Sradhanjali inform secretly to Pradeep about such matter over phone. Then Pradeep went to Sradhanjali's house, broke the lock and her caught red handedly. They were scaled on them that if their family members would come to know that, then they definitely be come hard so they left their home and went to Bhubaneswar. Both are settled in a rented house and used to work in one office. They lived together for seven years long at Bhubaneswar. Then in 2014 Pradeep's family arranged a girl for his marriage. Anyhow they convinced Pradeep but Pradeep kept it secret and did not tell to Sradhanjali. Pradeep lied to Sradhanjali and says he had to go for a sake of a work. Pradeep's family getting success to complete his marriage with another girl. Sradhanjali came to know about such matter after few days. At that time she was also pregnant for five months. Then after she tries so many times to meet Pradeep also tried to call him but Pradeep changed his mind. After so many attempts she could not meet Pradeep. Then she lodged a complaint against Pradeep in Laxmisagar (Bhubaneswar) police 
station. Pradeep was taken into police custody but few days later his family made him out on bail. Then as Pradeep's home near Ganjam, Sradhanjali lodged another complaint in Ganjam police station but no one to listen. Sradhanjali had no any other option except to give up. She returned to Bhubaneswar fighting lonely with her bad situation. She gave birth to a boy child. Now she works in an office and lives with painful memories of her past along with her son. She tries to give her best and dedicate her life in establishing her son in a good position. Now has no relation with her paternal family. Sradhanjali left her parents and all relationship, home to settle Pradeep as her life partner. But the man who enjoyed with the lady, made her pregnant and lastly he left her alone helplessly and with a son on her lap without a father's name. Our patriarchal society blames the lady for all what has happened and hardly any one blames the man who betrayed her and shattered her whole life. She is left to suffer in our patriarchal world order though many laws are enacted to punish these man.

\section{Case 5}

\section{Ms. Kalpana Behera}

Kalpana Behera is eldest daughter of her family. They were four sisters and one brother. Her father is a mechanic in profession. Kalpana was studying intermediate during 2010 at Rambha Jagannath Mahavidyalaya. She also lied to her parents for the sake of her boyfriend name as Gopinath Behera. Though she went for college but never attended present in class. Gopinath's village name is Palur. Gopinath studied till class. One day Kalpana went to her aunt's home along with Gopinath. Her aunt residing at village named as Kodala. Her aunt getting angry and shouted at Kalpana and told everything to Kalpana's father over phone. When Kalpana returned home her father rudely abused her and also heat her. Then after in morning Kalpana without informing her family went to Bangalore with her boyfriend. Her family tried to search her everywhere but did not found. After two to three months Kalpana talked with her mother over phone and said her out I that's loved someone and she was at Bangalore along with him. She also said, no need to worry for her, she was happy there. Then Kalpana's family promised her that if she come back then they may definitely give her in marriage with Gopinath. As a result they returned to their village but Gopinath's family did not agree for marriage. After so many trial they agreed but with a condition. They were demanding huge dowry. As Kalpana's father was a mechanic in profession, were not in position to fulfill such kind of demand. So they were not able to give her in marriage with Gopinath. After three to four months, they came to know that Kalpana was pregnant. Kalpana's parents again tried many times to convince Gopinath's family, requested and tried to give everything to their capacity but they were heartless and did not agree. They were blaming Kalpana with bad languages and abusing entire family. Then after Gopinath himself refused that the child growing Kalpana's womb has no relation with him.Kalpana's parents had no other option except to become silent .As they were in girls side. Kalpana's father suggested to Kalpana for abortion but she did not want to alort it. At that time Kalpana was only 17 years old. Kalpana wanted to birth to her child .Then after, in 2011 she gave birth to a boy child in her paternal home. After listening of Kalpana's delivery, Gopinath secretly came to meet his child and Kalpana. When two familyies came to know that Gopinath's family finally agreed and took them home with arranging marriage. Now they are enjoy spent their life together.

\section{Case 6}

\section{Ms. Rojina Mallick}

Rajina was 15 years old in 2014.She left her study when she was study class $\mathrm{V}^{\text {th }}$ and was looking after all household work. She did not continue her study as their financial condition was poor. They were two sisters and one brother. Rajina was eldest among them, brother was studying in class upper middle while sister was very small. At that time her brother was studying in at class $\mathrm{VI}^{\text {th }}$ and sister in class three. Both father and mother of Rajina were daily wage labours. When her father and mother went to their work, Rajina managed to cook and do all household work and also took care of her brother and sister.

Rajina had an uncle and he was also married. But they were residing in same village. When Rajina was getting some time from her work, she used to go to her uncle's house most of the time. Her uncle had a small boy. Rajina had good relation with her aunt. Her aunt had one brother and he never missed a chance to come to his sister's house when Rajina was there. He was unmarried. He was considered as uncle of Rajina in relation. His name was Murali Das. Murali was 24 years old. As they were meeting most of the times, their meeting slowly converted to love relation. But both of them were search to express their feelings. When Murali came after some day's gap he was bringing some gifts along with him and when they were meeting he used to give it to Rajina. In such situations Rajina's love towards Murali became more possessive and they did not want to spend a moment without seeing each other. Then one day both express their feelings and both accepted their love. Whenever they found themselves alone in home they tried to meet each other. Then after their love intimacy started growing day by day. None had noticed that. Murali approached many times and tried to convince Rajina for physical relation. In first attempt Rajina denied such proposal, then Murali showed his anger and left out. Rajina felt bad for that. After seven to eight days Murali came to his sister's home and that day they had physical relation and then they continued it many times. Few days later Rajina got ill and was taken into hospital for checkup. Report 
came out as she was five months pregnant. The parents of Rajina showed their reaction with abusing and also heat her. Rajina remained silent without expressing anything. Once her aunt called her secretly and asked about the matter. She told everything what had happened and also told to her mother. They know that, people would make it big issues and would raise a finger, so they hesitated to lodge a complaint against Murali. Then they had got suggestion from a doctor and they left Rajina in Basundhara of Cuttack. She gave birth to a girl child and then she left her child in orphanage. Keeping her future in mind she took such decision. Then she moved to her father's home. Her father restricted her to visit uncle's home. Now there is a dispute between two families. Rajina's father finished all relations with them. Rajina was warned by her father and mother that if she try to keep any relation with them, then they would commit suicide. Now Rajina has no relation with Murali.

\section{Case 7}

\section{Ms. Deepika singh}

Deepika Singh is a twenty four old lady from BadaBazar, Dist-Mayurbhanja. Her father's name is Lalit Singh. It was an incident of 2014. Deepika did not study higher and only managed to study till class $\mathrm{V}^{\text {th }}$ .They four sisters. Deepika was second eldest. Her elder sister did not get married due to poverty. Whatever proposal comes for them all demanded huge dowry.That is the cause for high proposals were rejected. Deepika's father has a small grocery shop and her mother worked as a daily wage laborer. They live their life with full of pain and difficulties. Two sister of deepika continued their study. One of sister studied intermediate and another was in class VIII ${ }^{\text {th }}$. Deepika never wanted to be a burden her family. She wanted to be self dependent.

So she came to Bhubaneswar in search of a suitable work. One of her childhood friend had settled in Bhubaneswar. Deepika came to Bhubaneswar after confirming with her friend. Her friend worked as peon in a office. Deepika stayed 15 days in her friend's room. The room was in IRC village of Bhubaneswar. Then after Deepika shifted to a new room (small cottage). That room was in Salia Street. She was not able to find a suitable work for her. Finally she had decided to work as a sex worker. It was the only way of income left for Deepika. So she started prostitution .Whatever money she income from such source was enough for her to live and she sent the rest of money to her home. Deepika's family had no idea about Deepika's profession. They think that Deepika had got a suitable work.

Deepika now has a large number of customers and she does it with many peoples. In this way her profession went on.Few days later she realized that she was having pregnant. When she got realized it becomes too late. After medical check up, she knew that it was in seven months pregnancy. Deepika had no option. She did not inform her family and went to Basundhara of cuttack by the help of a social worker. Her family was totally unknown about such occurrence. As she came alone from Mayurbhanja to Bhubaneswar to earning money. After

\section{Case 8 \\ Ms. Gayatri Hembram}

Gayatri Hembram was from a poor family. They were four sisters and three brothers. Gayatri was the eldest among all. Her father used to manage their family as daily wage labour. Gayatri had taken the responsibility of all younger brothers and sisters. Gayatri left her study since class $\mathrm{V}^{\text {th }}$. Three brothers of her were continuing their study. One was in $\mathrm{IX}^{\text {th }}$, second was in $\mathrm{V}^{\text {th }}$ and smallest brother was in $2^{\text {nd }}$ class. Gayatri never wanted to be burden on her parents.

Gayatri was loving a boy in her village. His name was Kuna. They had in relationship since last 3 years. Gayatri wanted to marry Kuna and her intention was very clear that, she did not want to trouble her parents as they had not enough savings to marry their daughters. For this reason Gayatri wanted a love marriage with Kuna. Gayatri's family also a women of that her decision of marriage to Kuna, as kuna helped so many times to his family and also was providing bring necessary household materials many times. Kuna came to Gayatri's home every day. He was know and familiar face for them.

Being three years in relationship they had also in physical relationship. Whenever Gayatri was denying denied for physical relationship, Kuna tried to convince her with marriage proposal. Kuna also threatened that if she refused to keep relation with her then he will marry another girl. In such emotional blackmailing Gayatri had no other options to accept. Gayatri had all relationship with kuna. When her father and mother used to go work, at that time Kuna used to come to Gayatri. After few months Gayatri got pregnant and without informing her parents she informed it to Kuna. At that time she was having six months of her pregnancy. After knowing pregnancy Kuna suggested for abortion. But it was too late for abortion. Then Gayatri got seriously ill. After medical checkup their parents also come to know about her pregnancy.

Gayatri's father discussed this matter with Kuna and asked him for marriage but Kuna refused such proposal. Her parents requested many times but all west in vain. With fear of public insult, requirement of money for police complaint was the reason as they did not lodge a complaint against Kuna. Gayatri's family had a relative in Cuttack. Gayatri's father discussed such matter with them. They suggested to leave Gayatri in Basundhara.

Sometimes her father and mother used to visit her to know the condition of Gayatri. Then after Gayatri gave birth to a boy child. Gayatri's parents left her child 
in a orphanage, but few days later the child was died. Now Gayatri is at her home and working as a daily wage labor. Her parents are looking for a marriage proposal and Gayatri is now also agreed to marry anywhere else.

\section{Case 9}

\section{Ms. Hasina Begam}

It was an Incident of 2014.Hasina Begam belongs to a Musilm family. Hasina lost her father in her childhood. There was no one except her mother. Even she did not complete her primary education due to lack of money. She belonged to a very poor family .They spent their lives with difficulty. At that time Hasina was 20 years old. There were only two members. One was Hasina and her mother. Both of them used to work in other's house to manage their life. Hasina was followed by a boy when she used to leave her work \& go to home. That boy everyday used to wait at the time when Hasina comes out. That boy also belonged to Muslim community. His name Jakir. As they met every day and their daily meeting slowly converted in to love affair.

Then after, they started to talk each other. Their love started to grow with the time. Hasina introduced Jakir to her mother and Jakir was also invited for dinner in Hasina's home. Hasina's mother was also impressed with Jakir. With support of mother their love received full permission \& used to grow day by day.

Jakir also used to bring special foods for Hasina and for her mother also. Hasina's mother trusted Jakir blindly. Sometimes Jakir stayed in Hasina's home telling lies to his natal family. Jakir had three brothers and two sisters. Jakir was second eldest son.

Elder brother and one of the sister also got married. Jakir left his study after studying to $9^{\text {th }}$ class. Jakir helped her father and brother in their garage. Their family belonged to middle class level.

Sometime Hasina makes excuse and stayed in home without going to her work. Jakir never wanted to miss such chance and he used to cames to Hasina's home and they spent most of the times with conversations and then they never hesitated to fulfill each others physical requirement. The love relation of both has no sense at all. As few days later Hasina become unwell and she got weak day by day.

Hasina suffered in fever, headache, Hasina's mother suspected her but hesitated to ask anything. Then Hasina was taken to medical by her mother and Jakir. After check-up doctor reported that she was six month pregnant. Hasina's mother told nothing to Jakir and came back to home on their half way to home, Jakir told them to wait for a while and he ran away. Hasina and her mother waited and waited but Jakir did not return. Then after reaching home Hasina's mother reacted and showed her anger. Hasina had no other option that being silent and to remain in was crying continuously. Hasina tried to convince her mother and told Jakir her was that not those kinds of boys. He is one of the good person and he can never cheat her. She consolidated herself and also her mother with a hope of Jakir would come back but Hasina was hiding her emotions and fears. They have waited more than a week but Jakir did not return. Hasina's mother had no more patience to wait, so she out find Jakir and reached at Jakir's house. Then she tells everything to Jakir's family and asking to search Jakir's address. But Jakir's family did not give the address of Jakir and said that Jakir did not came home since many days. Jakir's family did not take any responsibility of Jakir's fault and told that they would never accept that Hasina in any chest. They waited family that Jakir would come back. Hasina's mother returned home with was never full of tears.

Few days later one of the relative aunt of Hasina came to her house. She resided in Cuttack. She noticed that both mother and daughter remained depressed and asked the reason. Hasina's mother told everything to her. Except hasina's aunt no one in the village had known about such matter. Hasina also stopped to go work and also stopped going out of home. After listening all the matters Hasina's aunt suggested and informed about basundhara. After staying few months in Basundhara Hasina gave birth to a boy child. To save Hasina from people's criticism her aunt took all the responsibility of that child. Hasina now lived with her mother. Even now Hasina was waiting for Jakir. But Jakir's address was unknown to Hasina. Till now there are no marriage proposals for Hasina. Her mother waited for a proposal by which she can give in marriage to her daughter. Now Hasina is twenty one years old. Hasina still has confidence about Jakir's return, but never informed it to her mother. Both mother and daughter now are working as a daily wage laborer. Sometimes they visited their aunt's house to look and ask the conditions of the child. Hasina still have a dream of Jakir and hope Jakir would come to take her to his home and they would happily live their married life. But time we decide that whether Hasina's expectation would came true? Will Jakir return?

\section{Case 10}

\section{Ms. Ranga Behera}

Ranga Behera is a twenty seven year old lady from Sai Gabindapur, po- Sai gobindapur, dist-cuttack, father-Bainsi Behera. It was an incident of 2014. There is a girl named Ranga. Ranga was a daughter from a very poor family. There are three sisters and one brother. Ranga left her study after $6^{\text {th }}$ class. Her elder sister got married. Ranga was second elder daughter of her family. Ranga's younger sister is now studying in $\mathrm{V}^{\text {th }}$ class and her only brother continuing his graduation. Ranga's father and mother both are daily wage laborer. Every day they used to go to their work. Sometimes Ranga also goes to work but they were not getting fair wages. So Ranga decided to go outside that area of her village. She resided at Cuttack. Ranga 
stayed in a small cottage and used to work in several houses, as maid servant. Ranga's earned very little amount through these work. Every months Ranga sends money to her home from her meagre earning. As usual Ranga spent almost seven months there. When Ranga used to go for her work, a boy was following always her. One day that boy proposed to Ranga and Ranga also agreed on his proposal.

The boy was Bhaskar pradhan. He had a pan shop and Bhaskar also helped Ranga occasionally. Ranga discussed this matter with her family. Whenever Ranga came to her home, Bhaskar also came along with Ranga. Both went on bike. After knowing the family conditions of Ranga, Bhaskar promised to the parents of Ranga that he would definitely marry to Ranga. In such ways Bhaskar became very closer to Ranga's family. Ranga and Bhaskar were staying in one room together and they stepped ahead of love. Both had physical relationship. Ranga had faith on Bhaskar that she will marry him, that's why she never hesitated to be in physical relation with Bhaskar.

After few days Ranga realizes that she became pregnant. When ranga came to know that, she was already four month of pregnant. Then she discussed this matter with Bhaskar. But Bhaskar remained silent after listening about her pregnancy. After Ranga's pregnancy Bhaskar did not keep any physical relation with Ranga. Bhaskar tried to maintain distance from Ranga. Once Ranga asked Bhaskar about her family and address but bhaskar cleverly changed the conversation. Bhaskar did not tell anything about his family and address. Ranga was realized that bhaskar got irritate whenever she asked about his address so she stopped asking about his family .Ranga and Bhaskar kept physical relation after five months of her pregnancy. They know each other only for last one year.

One day Bhaskar escaped away from Ranga. Ranga tried to search him out everywhere, asked every person neared to him, but nothing happened. Finally she informed about this matter to her family. Ranga's family reacted seriously towards Ranga. They refused her to come home because if their villagers would to know about that, then they will offend Ranga's family. So Ranga was warned by her parents. Ranga's parents also searched bhaskar but no result. Then after Ranga was suggested to admit her in Basundhara. She gave birth to a girl child. Then Ranga left her daughter in an orphanage. Because Ranga wanted to think about her future. Basundhara has settled a work for Ranga in a family. Now Ranga is getting got 3000/- per month for her work. She used to send some money for her family and keeps the rest amount for herself.

\section{Case 11}

\section{Ms. Susuma Behera}

Susuma Behera is a 24 year old from Surangi village of Ganjam district. She was from a middle class family having yearly income of 1.5 lakh. She had a family of parents and 2 sisters. She was the youngest. She left her study in the $\mathrm{V}^{\text {th }}$ grade at age of 14 years, she had affairs with a 25 years old man named Trinath Behera, he was from Ichhapur.He had given an image that he was doing a business at her village for which he used to take large amount of money for Susuma frequently. He used to say he had 2 sisters one elder and another younger to him and has old parents.

Their first meet at Ichhapur which was a the parents home town of Susuma as well as the home town of Trinath. He Collected Susuma's phone number from one of their common friend. They started talking over phone for few days after that she used to meet him and go for film at Berhampur without any body's knowledge. Within that time they had started physical intimacy which they kept secretly from both of their families. She got pregnant. As soon as she new about her pregnancy she intimated about this to Trinatha and asked him to get marriage to her but he kept quite for three days and eloped from the village. Susuma got impatient and started searching for Trinatha everywhere and tried to do whatever she could do to find him but at last .The Couldn't find him anyway, she when to her parents as the last result her parents didn't expect their coming back. This gave them a big shuck. With anxiety impatient they reflected that Susuma physically and mentally abused to. They took her to the nearest medical MKCG for abortion. But the doctor refused for as abortion per the medical condition of the patient as. She was by that time five month carrying position. Her father couldn't bear the pain of defame of his doctor and his family and went through lot of stress which led to attack and than death. Susuma stayed at her maternal house and gave birth to her baby girl. To support her family, (includes mother, sister, daughter), she opened a grosshory stall. Keeping silent to the assault, taunt from everyone around her, she kept on raising her daughter with the help her mother and elder sister.

Out of blue, Trinatha arrived at the village with his wife and a son after two years from the day of his elope. Trinatha give second marriage proposal to Susuma. But susuma refused to it and say it is better to die than to be his wife who gave her hope and left her with the tears \& cries helplessness.

Now her daughter is in sixth grade, staying in Government hostel and pursuing her studies at Berhampur .Though susuma is getting a lot of marriage proposals these days , she is bluntly saying no to it ,With hardship she is facing the world .She is determined to make her daughter as a good human being and well educated one. That is the only motive of her life. Susuma is a good looking girl, many person proposed to marry her but with a conditions. But Susuma couldn't agree to these conditionality and till date she has remained unmarried. Susuma is living a life of pain and turmoil keeping the tears back within her eyes and within her heart. She as chewed all pathos and now staying alone in her house. Laws were set for another 
wedding but he turned the mind and warned her in laws that if they force again to marry then she would commit suicide or would leave home for life time. Since a that day no one is again asking or discussing about that. Now Susuma turned to twenty four. Now she is not worried about herself and her only motive is to make her daughter as good human being also trying to give her daughter a better future.

\section{Case 12}

\section{Ms. Shanti Majhi}

Shanti Majhi from Jhumpura village belongs to Keonjhar district. Shanti belongs to a very poor family. There was no one except her mother. She did not know her father. Her mother also had no idea about shanti's father. Lata and Shanti lived in small cottage in a slum. They used to collect fire woods from near forest and sold them in the market. It is the only source by which they were arranging their daily food.

Some people knew that Shanti spent most of times lonely when her mother went to forest. Once they forcibly entered into Shanti's cottage and force tally raped Shanti. Then they threatened that if she revealed anything about that then they would about that they will be murder her. So she was frightened and did not disclose that to anyone. After few days she came to know that she has become pregnant. Then she told everything to her mother. Due to poor financial condition they were not able to lodge a complain against them. Few months later, she gave birth to a boy child.

One day Shanti and her mother were caught when they were attempting to steal a child from a family. Then they were taken into police custody. Now they spent their life in imprisonment. Shanti along with her 6 months son now in Berhampur central jail and her mother was kept in Keonjhar jail. Shanti Majhi came to Berhampur jail for last 2 months. Now shanti is just 15 years old. As she is a teenager, she struggled to control her baby. She did not know who was the father of her child. So she tried so many times to kill her baby and kept her child hungry and she used to eat her food also. As she is immature, the other women prisoners tried to keep the child away from Shanti and tried to convince her. Shanti had no relatives and near one's as her mother was also a prisoner, so no one there to ask about her wellbeing. Shanti's child also suffering in such situation. The child also grows in that environment. He was frightened to face outside world. He also got afraid of outside people. What was her fault and why she got such big punishment? Is she responsible for that? The society has spoiled a girl's life. For such occurrence Govt. also did nothing for her. What steps should Govt take? Can govt returned her husband and has someone anywhere to marry her? Now Shanti spent her life as a prisoner in her teen age. Why such incidents are happening? Is there no right for girls to live? There exists is no truth and no justice in our society.
Sometimes society acts as respect and humble towards girls and women but it is nothing just only showoff. In another case it also happening in present time as in the name of religion and tradition try to make burden in her childhood. Can our society gave Shanti's childhood back??

\section{Case 13}

\section{Ms. Mrunmayee Behera}

Mrunmayee Behera was a mad girl. She was from Puri, Po-Niali, Dist-Puri. She was twenty eight years old. In 2014 she escaped from her home and came out to market life and never returned. Her family did not found her after so many tries. Mrunmayee used to bag in temple and spend nights on road sides. She did realize differences between good and bad. She was totally unknown about society. Some bad intentioned peoples notice her movement and tried to follow her. People tried to first with her and also try to convince her by giving food items etc. Their intention was to take the advantage of Mrunmayee's madness. Mrunmayee had no idea about people s' intention. Whenever people were getting Mrunmayee alone they used to rape her. Mrunmayee was unaware about such occurrence, because she had totally lost her mind power.

As days passes she became pregnant. But Mrunmayee had no idea about that. She just lived her life in abnormal way. As used to beg and live her life. By the time she was seven months of pregnancy she did not know that she was pregnant but except her everyone knew about her pregnancy. The place where Mrunmayee used to live was Niali. Once the Tahasildar of Niali noticed her and tried to convince her. Tahasildar was a good kind hearted person. He was success to convince Mrunmayee and took her to Basundhara (Cuttack).

Mrunmayee gave birth to a boy child, she stayed there along with her child for few days. After many days Mrunmayee's parents came to Puri for searching their daughter. Then they heard about the Tahasildar. They went to meet tahasildar. Tahasildar told everything and gave the address of Basundhara. The parents of Mrunmayee moved to Basundhara and left her child in an orphanage of Khorda and took Mrunmayee to their home. The father and mother of Mrunmayee were a daily wage laborer. They took careof their daughter and gave medicines regularly. As a result Mrunmayee recovered from madness and now she lives in Puri with her parents.

\section{Case 14}

\section{Ms. Rojalin Mallick}

Rojalin Mallick is a 35 years old from Bhadrak.poChandabali, dist-bhadrak. Rojalin was married to a mechanic of Chandabali. At that time she was twenty five years old. Her husband's name was Sidhu Mallick. Rojalin had mental problem. But Sidhu did not know about that. Few days after marriage sometimes Rojalin 
reacted like a mad persons.They had a son. Now their son is five year old. Sometime they got quarrel between both. Rojalin tried many times to leave the home but couldnot Sidhu's family consisted of eight members joint family having, father, mother, two brothers, two sisters and his wife Rojalin. But Rojalin did not have has not healthy relations with any member of Sidhu's family.

Sometime Rojalin was torchured physically and mentally by all members including Sidhu also. Rojalin had no contact with her parent's family. The reason she never expressed her pain and emotions to her near one's.

Rojalin was illiterate and never went to school. Her husband went to work every day. Everyday there was a disturbance in the family for even small issue. For this reason Rojalin's mental pressure used to increase higher. One day Afters sidhu's return from his daily labourer work, his family complained against Rojalin to Sidhu but Rojalin was not aware about that. Rojalin was innocent and all the members of her family tried to pull her leg. After this Rojalin escaped from her home and came to Bhubanswer. She had no relative or friends in Bhubaneswar. So she choosed railway station to spend her nights. She accepted bagging and she almost became half mad. After Rojalin's escape Sidhu's family got frightened that if Rojalin even discloses about her tortures in law and for that reason they started to search Rojalin, but could not find her.

Rojalin had surrived as she used to bag and it has been her daily life. There also few bad morality people tried to follow Rojalin. Their only intension was to take advantage of Rojalin's innocence and madness. So they executed a plan, as they offered some amount of money and food to her and they were successful to put Rojalin in trap. Those people used Rojalin as a sex machine. But Rojalin had no idea how she was used by those people. As usually few days later, Rojalin got seriously ille. She suffered in fever, headache and was not able to move anywhere. Her condition became terrible day by day. Some social workers was noticed her such condition and took her to Bhubaneswar medical .As per the report she was found five months pregnant. Then Rojalin was sent to Basundhara of Cuttack. She was given medicine regularly by care takers. She gaves birth to a girl child. Her daughter is now six months old. Neither her husbands family nor her father and mother were informed her motherhood about that. Rojalin also had no intention to go back to her husband. Now she lived life in Basundhara full of pain.

\section{Case 15}

\section{Ms. Rubina Begam}

Rubina is a 13 years old girl and belongs to Muslim community from-Darga Bazar, Cuttack district, father there Seikh Nizaudin and Rubina was the only daughter of her parents including two brothers. Rubina's father is used to pull rickshaw and earn livelihood and her mother works in others houses such as cleaning plates, of houses etc. After VII ${ }^{\text {th }}$ class Rubina stopped her study and looks all household work in her home. At such an early age she took the responsibilities of her family. Her two brothers continuing their study. There is a man about 49 year old has a shop which was nearer to Rubinas's home. Rubina's family brings all required goods from that shop. Most of times Rubina goes to that shop for purchasing goods and things' hat shopkeeper's name was Harihara Choudhury. Hari was sexually attracted to Rubina. But Rubina never noticed that. Hari was a married person, had a wife, three daughters and two sons. Though Hari used to was 49 years old, still he wanted to kee relation with loves rubina. Sometimes Hari used to give some goods from his shop, free of costs to Rubina. Such small things also created impression in Rubina's heart towards Hari. Sometimes Hari also helped in terms of money and bring daily use cosmetics etc for Rubina. These matters are unknow to Rubinas family. Rubina also kept it secret. These small things and caring was the reason as Rubina fell in love with Hari. Both were in love with in $3 / 4$ months of their conversation. When there is no one in Rubina's home, Hari used to come to rubina's home. Hari gifted mobile phone to Rubina through which he could confirm that whether she was alone or not.

Rubina's parents had no idea about such occurrence. When Hari used to receive a message of confirmation of her loveliness then, he used to come to Rubina's home and both kept physical relation and they continue it many times as and when they get a chance. Rubina was instructed by Hari to keep their relation her secret. For this Hari brings variety of gifts for Rubina and also offered money. Hari used Rubina for only sexual satisfaction. Few days later Rubina's health got in seriously and did not recover. So Rubina was taken to medical. Reports reported that Rubina was five months pregnant. Rubina's parents were shocked at this report and beaten,abused Rubina. Rubina by the time told everything what had happened between her and Hari Rubina's parents lodged a complaint against Hari in women's police station. Till the date the case is not solved. Within such incidents, Rubina gave birth to a girl child. There is a serious quarrel between Hari and Rubina's father. Haris shop has been closed. Keeping Rubina's future in mind, her child was left in an orphanage by her father. All these happened in 2014 . Now Rubinas struggle continue with their parents. She realizes for her early days mistakes. For such small happiness she took serious risks which spoiled her life.

\section{References}

1. Erickson, N, Mcclain, L, Omolade,B and Shalleck,A,(1980), "Discovering Our Connections: Race and Gender in Theory and Practice of the Law," The American University Journal of Gender \& the Law, and at the Feminism and Legal Theory Project's Workshop on Motherhood at Columbia 
University School of Law, pub:Columbia University School of Law,pp-204-205.

2. Crenshaw, K, (1989), "Demarginalizing the Intersection of Race and Sex: A Black Feminist Critique of

Antidiscrimination Doctrine", pub:Feminist Theory and Antiracist Politics, Columbia,pp-60-152.

3. Caldwell, P.M, (1991), "A Hairpiece: Perspectives on the Intersection of Race and Gender”, pub:Duke L.J,pp-115.

4. International Institute for Population Sciences, (IIPS), (2010), "District Level Household and Facility Survey", pub:2007-08: India. Orissa: Mumbai: IIPS, pp-3.

5. Graefe and Lichter, (2002), "Life time probability for marriage", pub:Robbins and McFadden, pp-5. 